\title{
MULTIDISCIPLINARY APPROACH IN THE SURGICAL TREATMENT OF COLORECTAL CANCER IN ELDERLY AND GERIATRIC PATIENTS AT HIGH OPERATIONAL AND ANAESTHETIC RISK
}

\author{
Pavelets K.V. ${ }^{1,2,3}$, Lobanov M.Y. ${ }^{1,4}$, Shishlikova Y.S. ${ }^{2}$, Rusanov D.S. ${ }^{1,3}$ \\ ${ }^{I}$ St. Petersburg State Pediatric Medical University of the Russian Ministry of Health, \\ St.Petersburg, e-mail: fox-kamchatka@mail.ru; \\ ${ }^{2}$ Northwestern State Medical University named after I. I. Mechnikov of the Russian Ministry \\ of Health, St. Petersburg, e-mail: rectorat@szgmu.ru; \\ ${ }^{3}$ St. Petersburg State Budgetary Healthcare Institution "Mariinsky City Hospital", \\ St.Petersburg, e-mail: admin@mariin.ru \\ ${ }^{4}$ St. Petersburg State Budgetary Healthcare Institution "City Hospital No. 26", \\ St.Petersburg,e-mail:b26@zdrav.ru
}

Aims

To improve the results of surgical treatment of colorectal cancer in elderly and geriatric patients through the application of the developed algorithm for perioperative management of patients at a high operational and anaesthetic risk.

Materials and methods

Immediate results of surgical treatment of 172 elderly and geriatric patients with colorectal cancer were analysed. The average age of patients was $75.3+8.2$ years. All patients were subdivided into two groups. The main group included 86 persons to whom an extended algorithm of perioperative management was applied taking into account additional echocardiographic indices, the control group included 86 persons who received a standard clinical and laboratory instrumental examination. The patients in both groups had a burdened polymorbidity background - at least two physical illnesses on average per patient and a high operational and anaesthetic risk on the MSSAR scale [Moscow Scientific Society of Anaesthesiologists and Resuscitators]. The extended diagnostic algorithm included an assessment of additional dopplerographic indicators in the preoperative period, on day 1 and 10-11 after surgery with the calculation of left ventricular systolic-diastolic ratio, the Tei index. The increase of the latter indicated the specific increase of the systolic component in the cardiac cycle and decrease in the efficiency of the left ventricular contractile activity, which is a predictor of left ventricular heart failure.

Results

Patients of the main group had a significant advantage in preventing the perioperative cardiovascular risk over the control group, which subsequently enabled the extension of operability, and thus an increase in the number of radical surgeries and reduction in the number of postoperative complications. The threshold value of the index, to the greatest extent reflecting the risk of acute left ventricular heart failure in the early postoperative period - on day 1 - turned out to be 0.79 .

Conclusions

The developed clinical and instrumental algorithm enables a more accurate assessment of the patient's condition and a more reliable prognosis of postoperative cardiovascular complications and hospital mortality in elderly and geriatric patients.

Keywords: colorectal cancer, Tei index, systolic-diastolic ratio, elderly and geriatric age.

\section{INTRODUCTION}

Colorectal cancer (CRC) is one of the main problems in modern clinical oncology. The analysis of the recent available publications revealed a tendency towards an increase in the morbidity rate of colorectal cancer worldwide $[1 ; 2]$. Annually, more than $1,200,000$ patients are diagnosed with colorectal cancer and 639,000 cases of lethal outcomes are registered because of the disease progressing. The statistics on the oncologic morbidity says that colorectal cancer occupies one of the leading places in the rank of oncological diseases in the economically developed countries (10-15\% from the total amount of cancer patients) [3; 4]. This pathology occupies the third place in the structure of the morbidity and the second place in the structure of lethality from oncologic diseases in the majority of the developed countries, including Russia [5; 6]. Annually, the morbidity rate increases by $2.3 \%$ and the lethality rate - by $3.4 \%$ [7]. It is expected that in the first part of the 21 st century, colorectal cancer will take the leading place in the structure of oncologic diseases [8]. 
Surgical treatment for colorectal cancer is the main component of modern effective therapy and the only method of radical resection of the tumor $[9 ; 10]$.

Presently, the rate of planned surgeries for CLC in older and senior patients with comorbid pathology is increasing $[11 ; 12]$. It is associated with the development of medical technologies and the demographic process of population aging. According to the experts from the International Society of Geriatric Oncology (SIOG), the often unsatisfactory outcome of the treatment of this group of patients is observed because of non-optimal evaluation of perioperative risks in patients with comorbid diseases $[13 ; 14]$. The outcomes of surgical treatment in older and senior patients with CLC are comparable with the outcomes in patients younger than 60 years old in the case of timely and adequately compensated nonsurgical nosologies.

A high rate of lethality within the 1 st year after the diagnostics of CLC is explained by the fact that the primary tumor is diagnosed at later stages (3rd-4th stages) in more than $70 \%$ of patients with colon cancer and $60 \%$ of patients with rectal cancer. Only $40 \%$ of these cases are surgically curable $[15 ; 16]$. There are still attempts to search for a simple, universal, and reliable parameter that would allow for the screening evaluation of the possibility of the development of cardiovascular complications during non-cardiac surgical interventions. There is a method of predicting cardiovascular complications in the early postoperative period by the analysis of anamnestic, clinical-instrumental, and laboratory risk factors using such scales as APACHE II, III, SOFA, SAPS I, II, MODS, etc. Besides, additional characteristics of the comorbid status are used, in particular, the modified Charlson index, ICED (Index of Co-Existent Disease), etc. [17].

In the majority of cases, the mentioned scales and indexes do not have precise quantitative criteria and do not take into account the peculiarities of age-related norms of functional parameters, especially, in patients from older age groups, which does not always provide adequate prognosis of the development of acute left ventricular failure in the early postoperative period. Thus, the development and implementation of additional echocardiographic criteria in the clinical practice, in particular, the Tei index, contributing to the increase in the precision of prognosis of possible acute left ventricular failure in patients that underwent surgical treatment for CLC, is quite promising. This approach in cardiologic practice is relatively simple, non-invasive, informative, and highly-efficient for the evaluation of hidden hemodynamic disorders that allows for the effective prognosis of postoperative cardiovascular complications.

The study was aimed to improve the results of surgical treatment for colorectal cancer in older and senior patients using the proposed algorithm of perioperative observation of patients with a high operativeanesthesiological risk.

\section{MATERIALS AND METHODS}

The analysis of the results of the examination and surgical treatment of 172 patients with CLC was performed. The study included patients aged 61 to 96 years old. All patients were divided into two groups. The main group included 86 patients aged $75.1 \pm 8.0$ years old. In this group, an extended algorithm of perioperative observation of patients was used, wherein the cohort was evaluated by specialists from a multidisciplinary team that included a cardiologist and a specialist on functional diagnostics, with the further calculation of the Tei index. The control group included 86 patients aged $75.6+8.4$ years old. In this group, the authors did not apply the proposed algorithm of diagnostics. The main group included 45 men and 41 women. The control group included 33 men and 53 women. In general, the share of men in these groups was $45.3 \%$ and the share of women was $54.7 \%$. By the age group, patients were divided into older (61-75 years old) - 96 patients, senior (76-90 years old) -69 patients, and long-living (90 years old and older) -7 patients (Table 1 ).

All patients from the main and control groups had a polycomorbid background (Table 2). On average, one patient had two and more diseases and was characterized by a high operative-anesthesiological risk by the scale of the Moscow Scientific Society of AnesthesiologistsReanimatologists (MSSAR) $(7.1+1.1$ and $6.7+1.1$ points, respectively). 
Distribution of the examined patients by age groups

\begin{tabular}{|l|c|c|c|c|c|c|}
\hline \multirow{2}{*}{$\begin{array}{c}\text { Age groups } \\
\text { (years) }\end{array}$} & \multicolumn{3}{|c|}{ Main } & \multicolumn{2}{c|}{ Total } \\
\cline { 2 - 7 } & \multicolumn{2}{|c|}{ Control } & \multicolumn{2}{c|}{} \\
\cline { 2 - 7 } & Abs. & $\%$ & Abs. & Abs. & $\%$ \\
\hline $61-75$ & 48 & 55.8 & 43 & 50.0 & 91 & 52.9 \\
\hline $76-90$ & 35 & 40.7 & 34 & 39.5 & 69 & 40.1 \\
\hline 90 and older & 3 & 3.5 & 4 & 4.7 & 7 & 4.1 \\
\hline Total & 86 & 100.0 & 86 & 100.0 & 172 & 100.0 \\
\hline
\end{tabular}

Table 2

The rate of comorbid pathology in patients from the studied groups

\begin{tabular}{|l|c|c|}
\hline \multicolumn{1}{|c|}{ Comorbid pathology } & Control group & Main group \\
\hline Stable effort angina & $44(51.2 \%)$ & $32(37.2 \%)$ \\
\hline Atherosclerotic cardiosclerosis & $80(93.0 \%)$ & $82(95.3 \%)$ \\
\hline Postinfarction cardiosclerosis & $23(26.7 \%)$ & $10(11.6 \%)$ \\
\hline Hypertensive disease of the 1st-3rd degree & $86(100 \%)$ & $86(100 \%)$ \\
\hline Chronic heart failure & $47(54.7)$ & $36(41.9 \%)$ \\
\hline Acute cerebrovascular event in the anamnesis & $15(17.4 \%)$ & $12(13.9 \%)$ \\
\hline
\end{tabular}

By the localization of the tumor, patients were divided into two groups: a malignant tumor of the rectosigmoid junction was diagnosed in $54.6 \%$ of patients from the main group and a malignant tumor of the rectum was diagnosed in $60.5 \%$ of patients from the main group.

Among the clinical peculiarities of patients from both groups, abdominal syndrome prevailed. In 109 patients from both groups, it was subjectively evaluated as the "most significant". At the same time, the pain itself, its localization, character, and intensity were different. Cramp-like pains prevailed in the main $(59.0 \%)$ and control (50.1\%) groups.

The instrumental part of the clinicalfunctional study additionally included the calculation of the Tei index. During the echocardiographic study, transthoracic apical access in the 5-chamber section was used in the mode of continuous-wave Doppler with simultaneous registration of transmitral and transaortic flows. The myocardial index (Tei index) was calculated as a sum of periods of isovolumetric contraction (IVCT) and isovolumetric relaxation (IVRT) divided by the ejection time (ET) by the formula: Tei= $($ IVCT+IVRT)/ET. Normally, the Tei index for the left ventricle was $0.36 \pm 0.04$. This parameter was evaluated in the preoperative period, on Day 1, and Days 10-11 after the surgery. These are the generally accepted endpoints that include potentially unfavorable clinical periods of condition worsening in patients with the development of cardiovascular complications.

When the Tei index of cardiac dysfunction was higher than 0.79 , patients had clinically-instrumental predictors of left ventricular heart failure diagnosed. The specified Tei index indicated an increase in the length of the systolic period in the cardiac cycle, which decreased the efficiency of the left ventricle contraction being a potential cause of the development of the left ventricle heart failure. Patients with such values of the Tei index were classified as the risk group. Further cardiotropic pharmacological correction prevented possible cardiovascular complications.

Statistical analysis of the obtained results was performed with the software package STATISTICA for Windows (ver. 7). The comparison of frequency characteristics (sex, complications, comorbid pathology) was made using non-parametric Yates tests (for small groups) and the Fisher test. 
The study protocol followed guidelines for experimental investigation with human subjects in accordance with the Declaration of Helsinki and was approved by the ethics committee. Written informed consent was obtained from each patient (or an official representative) before the study.

\section{RESULTS}

After the realization of the generally accepted standard preoperative diagnostic algorithm that included laboratory (clinical blood assay, biochemical blood assay, tests for hepatitis, HIV and syphilis, blood group and rhesus factor, common urine test) and functional methods of study (ECG, chest $\mathrm{X}$-ray and abdominal USI), all patients from the main group had the Tei index calculated additionally. Before the surgery, 27 out of 86 patients had the Tei index higher than the reference ( 0.41 to 0.89 ). This difference in values required a differentiated approach to the correction of possible cardiovascular complications. The threshold index value that reflected the risk of the development of acute left ventricular heart failure in the early postoperative period (Day 1) was 0.79 . Such an increase in the Tei index was registered in 16 patients. It should be noted that the most often clinical manifestations associated with a significant increase in the Tei index value were hypertensive conditions $(67 \%)$, myocardial ischemia (52\%) or their combination (38\%). The performed pathogenetic cardiotropic therapy compensated the mentioned alterations and, on Days 10-11 after the surgery, the Tei index was higher than 0.41 only in 4 patients. The specified data is presented in Table 3.

Based on the data obtained in patients from the group of high risk, additional preventive cardiotropic pharmacologic correction was performed during the postoperative treatment that was indicated by the results of the monitoring of the Tei index on Day 1 and Days 10-11 after the surgery.

Thus, patients from the main group had a significant advantage in the prevention of the risk of the development of cardiovascular complications in the postoperative period over the control group. In further, this allowed the surgeons to expand the operability and increase the number of radical resections (Table 4).

The analysis of the number of postoperative complications in both groups using the method of prognosis of early postoperative cardiovascular complications in patients that underwent radical surgical treatment for colorectal cancer (92 patients: 67 patients from the main group, 25 patients from the control group) showed that the highest rate of complications was observed in the control group (12.0\%) (11 patients) and in the main group ( $7.6 \%)$ (7 patients). The specified data is presented in Table 5.

Table 3

Dynamics of the Tei index in patients from the main group in the postoperative period

\begin{tabular}{|l|c|c|}
\hline \multirow{2}{*}{ Period } & \multicolumn{2}{|c|}{ Tei-index } \\
\cline { 2 - 3 } & $0.36 \pm 0.04$ & $0.41-0.89$ \\
\hline Before the surgery & 59 & 27 \\
\hline On Day 1 & 70 & 16 \\
\hline On Days 10-11 & 82 & 4 \\
\hline
\end{tabular}

Table 4

Structure of the performed surgical intervention

\begin{tabular}{|l|c|c|c|}
\hline \multicolumn{1}{|c|}{ Outcome } & Control group & Main group & Total \\
\hline Abdominoperineal extirpation & $13(15.12 \%)$ & $50(58.14 \%)$ & 63 \\
\hline Anterior resection & $12(13.95 \%)$ & $17(19.77 \%)$ & 29 \\
\hline Hartmann's operation & $16(18.6 \%)$ & $14(16.28 \%)$ & 30 \\
\hline Stoma exteriorization & $43(50.0 \%)$ & $5(5.81 \%)$ & 48 \\
\hline Other & $2(2.33 \%)$ & 0 & 2 \\
\hline
\end{tabular}


Postoperative cardiovascular complications in patients that underwent radical resection $(n=92)$

\begin{tabular}{|l|c|c|}
\hline \multicolumn{1}{|c|}{ Outcome } & $\begin{array}{c}\text { Control group } \\
(\mathrm{n}=25)\end{array}$ & $\begin{array}{c}\text { Main group } \\
(\mathrm{n}=67)\end{array}$ \\
\hline Acute myocardial infarction (AMI) & $4(16.0 \%)$ & $2(2.9 \%)$ \\
\hline Pulmonary artery thromboembolism (PATE) & $2(8.0 \%)$ & $1(1.5 \%)$ \\
\hline Heart rhythm disorder & $3(12.0 \%)$ & $2(2.9 \%)$ \\
\hline Congestive heart failure & $2(8.0 \%)$ & $2(2.9 \%)$ \\
\hline
\end{tabular}

The comparative analysis in both groups revealed that the leading place in the structure of surgical complications is occupied by septic-inflammatory complications in the surgical site, in particular, suppuration on the laparotomy wound side in the main group in $3(3.5 \%)$ patients and in the control group in 5 patients $(5.8 \%)$, which was associated with Hartmann's operation and colostomy exteriorization. In the area of the perineal wound in the main group, seroma of the blind suture was observed in 3 patients (3.5\%) and suppuration in the perineal area - in 4 patients $(4.7 \%)$ after the tamponing of the presacral space. The second place by the rate of occurrence was occupied by an intraabdomi- nal hemorrhage. In patients from the main group, it was observed in $2.3 \%$ cases ( 2 patients) (anterior resection and abdominoperineal extirpation). In the control group, there were $4.7 \%$ of such cases (4 patients), 2 of them (anterior resection) underwent relaparotomy. The structure of postoperative complications also included early adhesive obstruction. Each group contained 1 patient $(1.2 \%)$ that had to underwent treatment for early adhesive small bowel obstruction. Both patients underwent relaparotomy. In the rest 77 patients $(89.5 \%)$ from the main group and in 72 patients $(83.6 \%)$ from the control group, the postoperative period was uncomplicated (Figure 1).

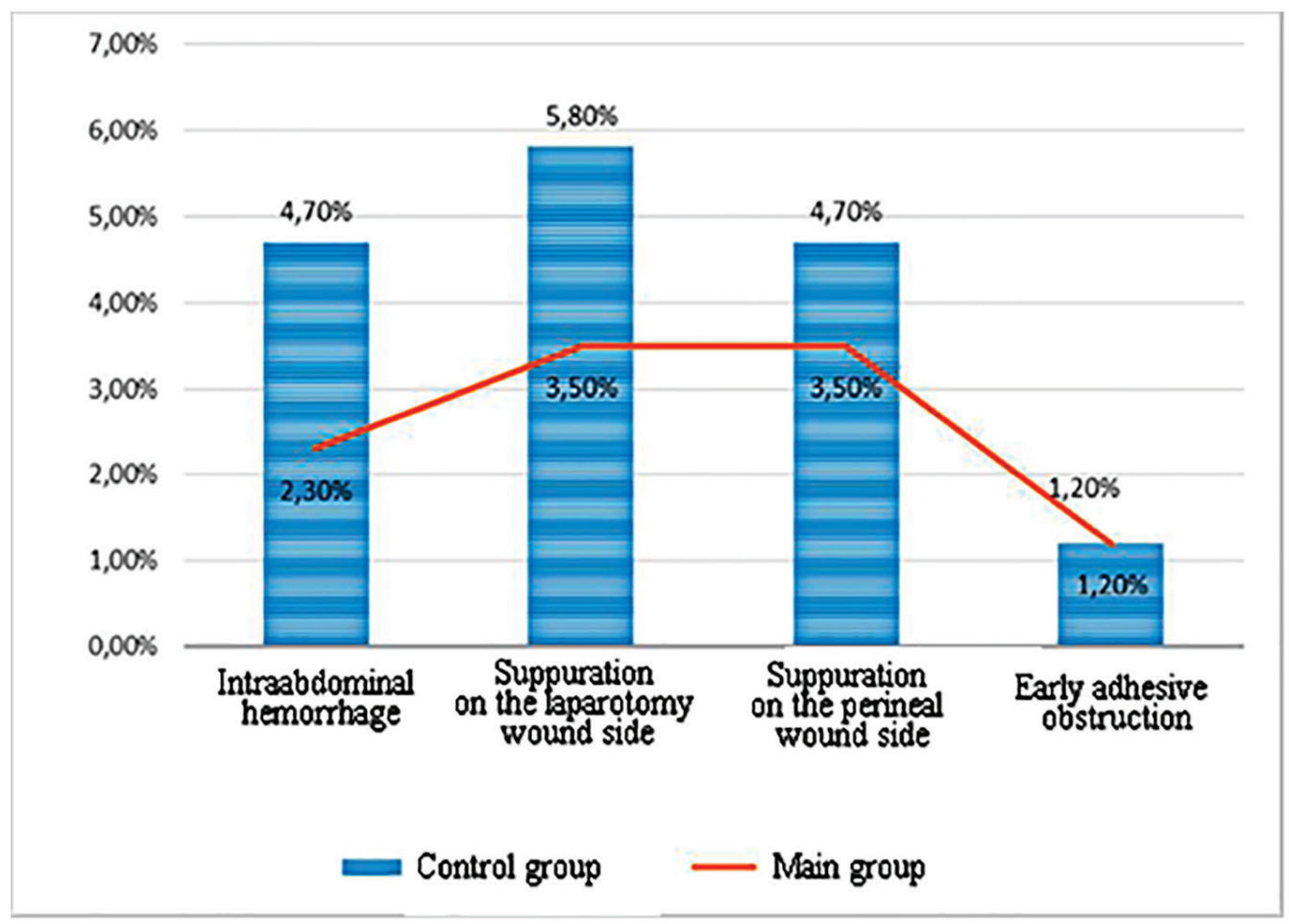

Fig. 1. Postoperative surgical site complications 
Causes of lethal outcome in the studied groups

\begin{tabular}{|c|c|c|}
\hline Causes of lethal outcome & Control group $(\mathrm{n}=86)$ & Main group $(\mathrm{n}=86)$ \\
\hline Multiple organ failure & $10(11.6 \%)$ & $3(3.5 \%)$ \\
\hline AMI & $5(5.8 \%)$ & $1(1.2 \%)$ \\
\hline PATE & $7(8.1 \%)$ & $1(1.2 \%)$ \\
\hline
\end{tabular}

The postoperative lethality in all the operated patients $(\mathrm{n}=172)$ was $5.8 \%$ (5 patients) in the main group and $25.5 \%$ (22 patients) in the control group.

A comparative analysis of the causes of the lethal outcome in patients from both groups $(n=172)$ showed that multiple organ failure had the highest rate. In the control group, it was $11.6 \%$ (10 people) and in the main group, it was $3.5 \%$ (3 people). Four out of ten patients from the control group had anterior resection of the rectum, one abdominoperineal extirpation, and five sigmostoma exteriorization as a palliative method of treatment. Three patients from the main group had a different volume of surgical treatment. One patient had anterior resection of the rectum, the second - Hartmann operation, and the third - sigmostoma exteriorization. These three patients were operated for upper and middle ampullary rectal cancer. Despite the performed pharmacological therapy and prevention of cardiovascular complications, in the postoperative period, there were lethal cases caused by acute myocardial infarction and pulmonary artery thromboembolism: 1 and 1 patient $(1.3 \%)$ in the main group and $5(5.8 \%)$ and 7 patients $(8.1 \%)$ in the control group (Table 6).

\section{CONCLUSIONS}

A multidisciplinary approach that involves additional functional-diagnostic and instrumental methods, in particular, Doppler echocardiography with the calculation of the Tei index, allows for the prognosis of early left ventricular heart failure in the postoperative period. This provides a possibility to optimize surgical treatment of colorectal cancer in older patients with a polycomorbid background, compensate cardiovascular risk, increase the operability, and decrease the rate of postoperative complications.

\section{FINANCIAL SUPPORT AND SPONSORSHIP Nil.}

\section{CONFLICTS OF INTEREST \\ The authors declare no conflict of interest}

\section{REFERENCES}

1. Afanasyev S.G., Startseva Z.A., Dobrodeev A.Y. et al. Immediate results of radical surgery under conditions of combined modality treatment of rectal cancer. [Neposredstvennye rezul'taty radikal'nykh operatsii v usloviiakh kombinirovannogo lecheniia raka priamoi kishki]. Siberian journal of oncology Sibirskij onkologiceskij zurnal, 2016, vol. 15, no. 1, pp. 5-10, doi 10.21294/1814-4861-2016-15-1-5-10.

2. Prorokov V.V., Vlasov O.V. The modern strategy of coloreactel cancer treatment [Strategiia lecheniia kolorektal'nogo raka]. Pirogov Russian Journal of Surgery - Khirurgiya. Zhurnal imeni N.I. Pirogova, 2013, no. 6, pp. 92-96.

3. Vasil'ev S.V., Popov D.E. Surgical treatment for patients of elderly and senile age with locally advanced colon cancer [Puti uluchsheniia neposredstvennykh rezul'tatov khirurgicheskogo lecheniia bol'nykh rakom priamoi kishki]. Grekov's Bulletin of Surgery - Vestnik khirurgii im. I.I. Grekova, 2016, no. 4, pp. 24-31, doi 10.24884/0042-4625-2016-175-4-24-31.

4. Glushkov N.I., Gorshenin T.L. Treatment of patients with complications of colon cancer in conditions of multifield gerontological hospital [Lechenie patsientov s oslozhneniiami raka obodochnoi kishki v usloviiakh mnogoprofil" nogo gerontologicheskogo statsionara]. Grekov's Bulletin of Surgery - Vestnik khirurgii im. I.I. Grekova, 2016, vol. 175, no. 3, pp. 73-79, doi 10.24884/0042-4625-2016-175-3-73-78. 
5. Manikhas G.M., Khalikov A.D., Khanevich M.D. et al. Results of enhanced recovery protocol in gerontological patiens with colon cancer [Rezul'taty vnedreniia protokola gerontologicheskikh bol'nykh rakom obodochnoi kishki]. Grekov's Bulletin of Surgery - Vestnik khirurgii im. I.I. Grekova, 2017, vol. 176, no. 1, pp. 60-64, doi 10.24884/0042-4625-2017-176-1-60-64.

6. Maistrenko N.A., Khvatov A.A., Sazonov A.A. Postoperative complications of combined surgeries in patients with disseminated forms of colon cancer [Posleoperatsionnye oslozhneniia kombinirovannykh vmeshatel'stv u bol'nykh s rasprostranennymi formami raka tolstoi kishki]. Grekov's Bulletin of Surgery - Vestnik khirurgii im. I.I. Grekova. -2017, vol. 176, no. 2, pp. 86-94, doi 10.24884/0042-4625-2017-176-2-86-94.

7. Khrykov G.N., Manichas G.M., Strukov E.Y. et al. Influence of nutritive support on surgery outcomes in elderly patients with colon cancer [Vliianie nutritsionnoi podderzhki na rezul'taty khirurgicheskogo lecheniia raka obodochnoi kishki u gerontologicheskikh bol'nykh]. Grekov's Bulletin of Surgery - Vestnik khirurgii im. I.I. Grekova, 2014, vol. 173, no. 3, pp. 77-81, doi 10.24884/0042-4625-2014-173-3-77-81.

8. Maistrenko N.A., Khvatov A.A., Sazonov A.A. Cytoreductive operations in treatment of the patients of elderly and senile age with disseminated forms of colorectal cancer [Tsitoreduktivnye operatsii pri disseminirovannykh formakh kolorektal'nogo raka u bol'nykh pozhilogo i starcheskogo vozrasta]. Grekov's Bulletin of Surgery - Vestnik khirurgii im. I.I. Grekova. - 2016, vol. 175, no. 2, pp. 30-35, doi 10.24884/0042-4625-2016-175-2-30-35.

9. Manikhas G.M., Khrykov G.N., Fridman M.Kh. Clinical recommendations for the treatment of colorectal cancer in elderly and senile patients [Klinicheskie rekomendatsii po lecheniiu kolorektal'nogo raka u bol'nykh pozhilogo i starcheskogo vozrasta]. Advances in gerontology - Uspekhi gerontologii, 2013, vol. 26, no. 3, pp. 458-468.

10. Prytz M., Angenete E., Bock D. et al. Extralevator Abdominoperineal Excision for Low Rectal Cancer - Extensive Surgery to Be Used With Discretion Based on 3-Year Local Recurrence Results: A Registry-based, Observational National Cohort Study. Annals of Surgery. 2016, vol. 263, no. 3, pp. 516-521, doi 10.1097/sla.0000000000001237.

11. Khalilov Z.B., Kalinichenko A.Yu., Azimov R.Kh. Minimally invasive surgery for colorectal cancer in advanced age patients [Mini-invazivnaia khirurgiia kolorektal'nogo raka u bol'nykh pozhilogo i starcheskogo vozrasta] Pirogov Russian Journal of Surgery - Khirurgiya. Zhurnal imeni N.I. Pirogova, 2018, no. 3, pp. 76-81, doi 10.17116/hirurgia2018376-81.

12. Zitta D.V., Terekchina N.A., Subbotin V.M. Clinical and biochemical evaluation of the effectiveness of fast track protocol in elective colorectal surgery [Kliniko-biokhimicheskaia otsenka effektivnosti programmy optimizatsii perioperatsionnogo vedeniia bol'nykh v planovoi kolorektal'noi khirurgii]. Coloproctology - Koloproktologiia, 2015, vol. 52, no. 2, pp. 18-29.

13. Singaevsky A.B., Tsikoridze M.Yu. Optimization of surgical tactics in case of complicated colon cancer in multidisciplinare hospital. [Sovershenstvovanie khirurgicheskoi pomoshchi pri oslozhnennom rake obodochnoi kishki v mnogoprofil'nom statsionare]. Herald of North-Western State Medical University named after I.I. Mechnikov - Vestnik Severo-Zapadnogo gosudarstvennogo meditsinskogo universiteta im. I.I. Mechnikova, 2014, vol. 6, no. 1, pp. 59-65.

14. Lyadov V.K., Kochatkov A.V., Negardinov A.Z. Standardized enhanced recovery protocol improves outcomes after colorectal resections in elderly patients. [Vliianie standartizirovannogo protokola uskorennogo vyzdorovleniia na rezul'taty radikal'nykh rezektsii tolstoi kishki u bol'nykh starcheskogo vozrasta]. Coloproctology - Koloproktologiia, 2017, vol. 61, no. 3, pp. 40-44.

15. Erokhina E.A., Topusov E.G., Topuzov E.E. Postoperative intraperitoneal complications in colon cancer surgery [Posleoperatsionnye vnutribriushnye oslozhneniia v khirurgii raka tolstoi kishki] Grekov's Bulletin of Surgery - Vestnik khirurgii im. I.I. Grekova, 2014, vol. 173, no. 3, pp. 63-67, doi 10.24884/0042-4625-2014-173-3-63-67.

16. Khomyakov E.A. Surveillance after curative surgery of colorectal cancer. [Dinamicheskoe nabliudenie bol'nykh kolorektal'nym rakom posle radikal'nykh operatsii]. Coloproctology - Koloproktologiia, 2015, vol. 52, no. 2, pp. 57-66.

17. Tsarkov P., Kravchenko A., Markaryan D. et al. Colorectal cancer surgery in elderly in Russia: risk factors and results. Colorectal Disease, 2016, vol. 18, Suppl. 1, p. 87.

18. Tsarkov P.V., Markar'ian D.R., Nikoda V.V. Multidisciplinary approach in the perioperative management of patients with colorectal cancer in old age [Mul'tidistsiplinarnyi podkhod v perioperatsionnom vedenii bol'nykh kolorektal'nym rakom v starcheskom vozraste]. Coloproctology news - Novosti koloproktologii, 2011, no 1, p. 50. 